\title{
The model of combustion process in the marine 4-stroke engine for exhaust gas composition assessment
}

\begin{abstract}
The paper presents the model of combustion process in the marine, turbocharged, 4-stroke and Diesel engine. The main target of modeling is the assessment of the exhaust gas composition. Presented multi-zone, 3-D model of combustion process consists of the following sub-models of processes: the fuel injection, the brake-up and the evaporation of fuel and the turbulence flow and the heat transfer phenomena. Presented model basis on the 3Z-ECFM mechanism of combustion and the initial and boundary conditions collected during direct measurements. The positive validation of the calculation results are obtained for mean and maximum value of the combustion pressure and values of oxygen and nitric oxides fractions in the exhaust gas. Unfortunately, fractions of carbon compounds in the exhaust gas are not properly calculated.
\end{abstract}

Key words: marine diesel engine, model, combustion process, exhaust gas composition, computational fluid dynamics

\section{Model procesu spalania w 4-suwowym silniku okrętowym do oceny składu spalin}

\begin{abstract}
Praca prezentuje model procesu spalania 4-suwowego, turbodoładowanego, okrętowego silnika o zapłonie samoczynnym. Celem modelowania byta ocena składu emitowanych spalin. Model ten to wielostrefowy, trójwymiarowy model spalania, obejmujacy proces wtrysku, rozpylania i parowania paliwa wraz z towarzyszacymi im zjawiskami turbulentnego przeptywu i wymiany ciepta. Model oparty jest na mechanizmie procesu spalania 3Z-ECFM oraz warunkach poczatkowych i brzegowych, zebranych podczas pomiarów bezpośrednich. Uzyskano pozytywne wyniki walidacji w stosunku do średniego i maksymalnego ciśnienia spalania oraz zawartości tlenu i tlenków azotu w spalinach. Nie uzyskano poprawnych wyników modelowania dla udziałów związów węgla w spalinach.
\end{abstract}

Słowa kluczowe: okrętowy silnik spalinowy, model, proces spalania, skład spalin, komputerowa dynamika płynów

\section{Introduction}

Gradually strengthened regulations relating to the marine environment protection, determine the development of marine Diesel engines. Since 1997 year International Maritime Organization introduces Annex VI to the MARPOL convention, entitled "Prevention of Air Pollution from Ships" [30]. The regulations of the mentioned Annex require manufacturers and operators of marine engines necessity to reduce emissions of nitrogen oxides $\left(\mathrm{NO}_{\mathrm{x}}\right)$. Mentioned regulations were extended to chapter 4 since 2011 year. This chapter requires ship operators' and ship manufacturers' necessity to limit the carbon oxides emission $\left(\mathrm{CO}_{2}\right)$ based on Energy Efficiency Operational Indicator (EEOI) [10]. Therefore, many works are carried out to improve the efficiency of marine diesel engines while simultaneously reducing the $\mathrm{NO}_{x}$ emission. These works consist in, among others, the design of the organization of the combustion process in the cylinder. It should be noted that the prediction of the composition of the exhaust gas requires a complete analysis of the processes occurring in the engine cylinder. The complete analysis of the fuel injection, the brake-up and the evaporation of fuel, the auto-ignition and flame propagation is required. The effective and inexpensive tool used in the design of internal combustion engines are methods based on Computational Fluid Dynamics (CFD).

\section{Wprowadzenie}

Sukcesywnie zaostrzane przepisy dotyczące ochrony środowiska morskiego determinują rozwój konstrukcji okrętowych silników tłokowych. Już w 1997 roku Międzynarodowa Organizacja Morska wprowadziła Załącznik VI do Konwencji MARPOL pt. „Prawidła zapobiegania zanieczyszczeniu powietrza przez statki" [30]. Przepisy tego załącznika nakładają na producentów i operatorów silników tłokowych konieczność zmniejszania emisji tlenków azotu $\left(\mathrm{NO}_{\mathrm{x}}\right)$. Przepisy te zostały zaostrzone w 2011 roku przez rozszerzenie Załącznika VI o rozdział 4, z którego wynika, że armatorzy i producenci statków zobowiązani są do zmniejszania emisji tlenków węgla $\left(\mathrm{CO}_{2}\right)$ przez statki, opierając się na wskaźniku efektywności wykorzystania energii (Energy Efficiency Operational Indicator - EEOI) [10]. W związku z tym prowadzone są prace nad poprawą efektywności silników okrętowych przy jednoczesnym zmniejszaniu emisji $\mathrm{NO}_{x}$. Prace te sprowadzają się miedzy innymi do projektowania organizacji procesu spalania $\mathrm{w}$ cylindrze silnika. Należy nadmienić, że predykcja składu spalin wymaga pełnej analizy procesów zachodzących w cylindrze silnika: od wtrysku paliwa, poprzez rozpylanie, parowanie, zapłon, do rozprzestrzeniania się płomienia. Skutecznym i tanim narzędziem wykorzystywanym $\mathrm{w}$ projektowaniu silników tłokowych są metody oparte na komputerowej mechanice płynów (Computational Fluid Dynamics - CFD). 
Arrègle et al. [1] present 0 -dimensional model of combustion process basis on parameters of the one cylinder, Diesel engine with a cylinder capacity equals $1854 \mathrm{~cm}^{3}$ and $350 \mathrm{~cm}^{3}$. Presented model allows to calculation of thermodynamic parameters of the combustion process such as rate of heat release (RORH), but not allows to prediction of the exhaust gas composition. Similar model was presented i.e. in [7]. Zhou et al. [31] present the multi-zone model for small Diesel engine in relation to marine engines. This model consists of 0 -dimensional mathematical description of the brake-up, the evaporation and the combustion of fuel. This approach to modeling made it possible to determine the content of $\mathrm{NO}_{x}$ and soot in the exhaust gas, but quantitative validation of calculation results was presented only in relation to thermodynamic parameters. Multi-zone models were presented by Şahin et al. [25] and Rakopoulos et al. $[23,24]$. Rakopoulos' models were additionally extended to chemical kinetic equations. Model of the combustion process based on the moving mesh of the combustion chamber is presented by Mohamed Ismail et al. [18]. Such model, prepared for light duty Diesel engine allows to qualitative mapping of the effect of injection timing on the changes of the NO concentration in the cylinder. Similar model, presented in [28], allows to analysis of the both pressure and temperature distribution during the cylinder scavenging. Still up to date overview of combustion models in the engine cylinders was presented in [5] and in [17, 22]. It should be noted, that presented models were prepared for the engines with small cylinder capacity in relation to the cylinder capacity of marine engines. For this reason, the main scientific aim of the paper is the preparation of the multi-zone and 3-dimensional model of the combustion process in the marine diesel engine to predict the exhaust gas composition.

\section{The model description}

Presented model was prepared on the basis of the moving mesh of the combustion chamber of the marine 4-stroke Diesel engine. Mentioned mesh was prepared for overall volume of the engine cylinder and allows preparing the calculations for full crankshaft rotation. Due to the relatively large size of the marine engine cylinder the mesh consisting of 500,000 finite volumes for the combustion stroke, and 1.5 million finite volumes for other strokes of the engine. The maximum size of finite volumes equals $8 \mathrm{~mm}$. In areas where the fuel injection and the combustion process occurs the mesh was compacted to 1-2 mm. Near the cylinder valves' faces, during valves opening and closing, the size of finite volumes was compacted to $0.125 \mathrm{~mm}$. The moving mesh was prepared using "Fame Engine Plus" tool from the AVL Fire software on the basis of technical documentation of the engine. The geometric dimensions, cylinder valves governing, piston moving and the characteristic of fuel injection were used to prepare the mentioned mesh. Mentioned tool from the AVL Fire software allows to limit the size of the mesh during the modeling of the combustion process to the space of the cylinder without inlet and
Arrègle $\mathrm{i}$ in. [1] zaprezentowali 0-wymiarowy model procesu spalania, opierając się na parametrach jednocylindrowych silników o zapłonie samoczynnym o pojemności skokowej $1854 \mathrm{~cm}^{3}$ i $350 \mathrm{~cm}^{3}$. Model ten umożliwia obliczenie parametrów termodynamicznych procesu spalania, takich jak szybkość wytworzonej energii cieplnej (rate of heat release-ROHR), ale nie pozwala na predykcję składu spalin. Podobny model zaprezentowano m.in. w pracy [7]. Zhou i in. [31] zaprezentowali model wielostrefowy dla niewielkiego, w stosunku do silników okrętowych, silnika o zapłonie samoczynnym. Model zawiera bezwymiarowy opis matematyczny procesu rozpylania, parowania i spalania paliwa. Takie podejście do modelowania umożliwiło określenie zawartości $\mathrm{NO}_{\mathrm{x}}$ i sadzy, ale ilościową walidację wyników modelowania zaprezentowano w pracy tylko w stosunku do parametrów termodynamicznych. Model wielostrefowy został również zaprezentowany przez Şahina $\mathrm{i}$ in. [25] oraz Rakopoulosa i in. [23]. Modele Rakopoulosa dodatkowo został rozszerzony o równania kinetyki chemicznej. Mohamed Ismail i in. zaprezentowali model procesu spalania oparty na ruchomej siatce przestrzennej komory spalania silnika [18]. Model taki, wykonany dla lekkiego silnika o zapłonie samoczynnym, pozwolił na jakościowe odwzorowanie wpływu kąta wyprzedzenia wtrysku na zmiany stężenia NO w cylindrze silnika. Podobny model, prezentowany w pracy [28], pozwolił na analizę rozkładu ciśnienia i temperatury podczas przepłukania cylindra. Aktualny przegląd modeli procesu spalania w cylindrze silnika tłokowego zaprezentowano także w publikacjach $[5,17,22]$. Należy zaznaczyć, że prezentowane modele przygotowano dla silników o małej pojemności skokowej - w stosunku do pojemności silników okrętowych. Z tego względu celem pracy jest sporządzenie trójwymiarowego i wielostrefowego modelu procesu spalania w cylindrze silnika okrętowego, aby ocenić skład spalin.

\section{Opis modelu}

Prezentowany model zbudowano na podstawie ruchomej siatki przestrzeni cylindrowej silnika. Siatkę sporządzono dla całej objętości cylindra i umożliwia ona przeprowadzenie obliczeń dla pełnego obrotu wału korbowego. Ze względu na stosunkowo duże wymiary cylindra silnika okrętowego zastosowano siatkę składającą się z 500 tysięcy objętości skończonych dla suwu pracy i 1,5 miliona objętości skończonych do modelowania wymiany czynnika roboczego. Zastosowano maksymalny rozmiar objętości skończonych równy $8 \mathrm{~mm}$. W obszarach, w których następuje wtrysk i spalanie paliwa siatka została zagęszczona do 1-2 mm. W okolicach przylgni zaworów w chwili ich otwierania i zamykania rozmiar objętości skończonych siatki został zagęszczony do 0,125 mm. Siatkę zbudowano za pomocą narzędzia „Fame Engine Plus” programu AVL Fire na podstawie dokumentacji technicznej silnika z uwzględnieniem wymiarów konstrukcji cylindra silnika wraz z rozrządem zaworów, ruchem tłoka i charakterystyki wtrysku paliwa. Wspomniany moduł programu AVL Fire umożliwia zmniejszenie wielkości siatki podczas modelo- 


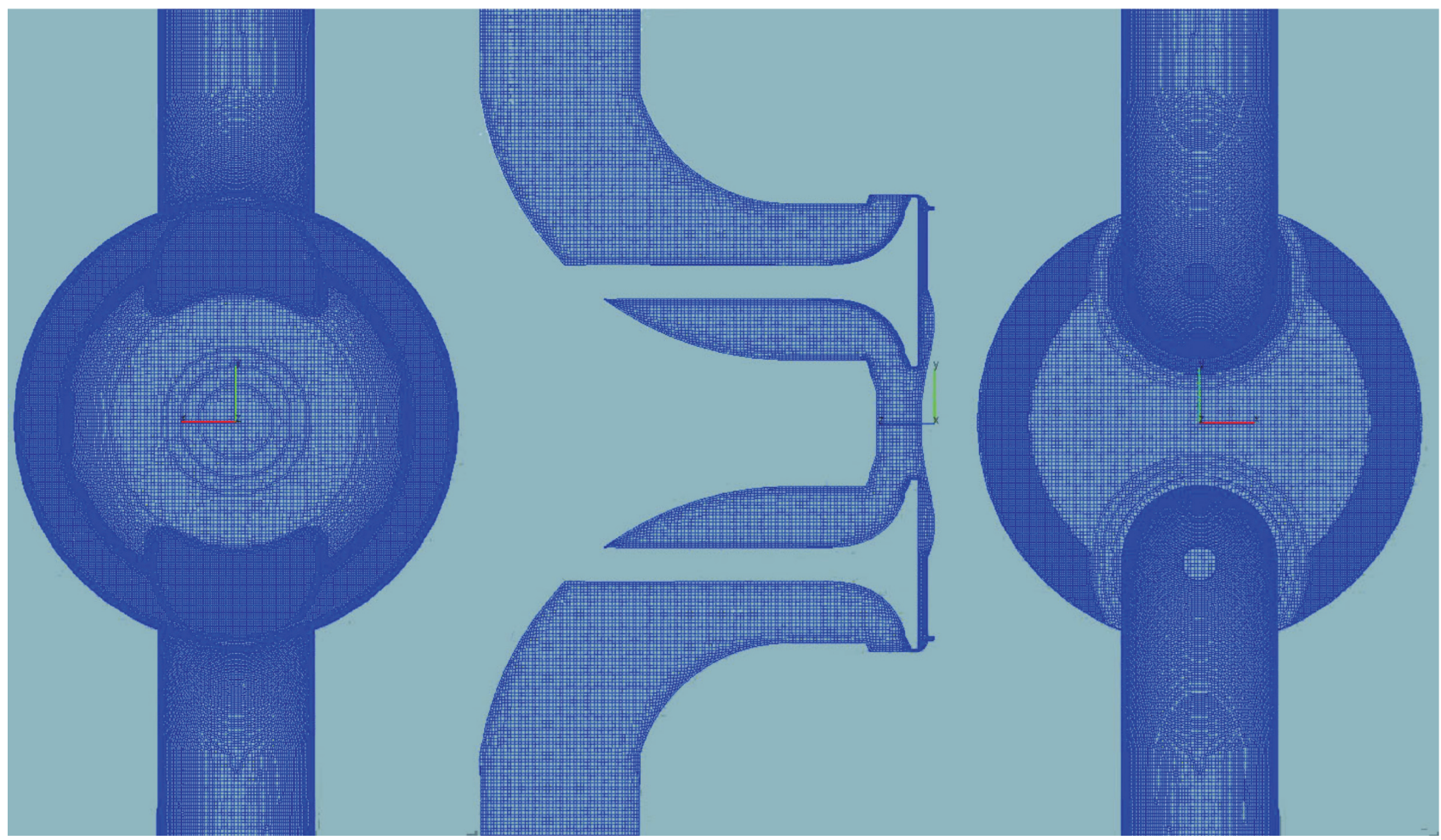

Fig. 1. Projections of the moving spatial mesh at the time of the cylinder scavenging Rys. 1. Rzuty ruchomej siatki przestrzennej w chwili przeplukania cylindra

outlet ducts. This approach greatly reduces the calculation time. The detailed description of the moving mesh design is presented in [16] and projections of the moving spatial mesh at the time of the cylinder scavenging are presented in the Fig. 1.

Model of fuel delivery into the cylinder requires the determination of the fuel injection parameters, which significantly influence on the combustion process and consequently on the composition of the exhaust gas. These parameters of the injected fuel are: the angle of the fuel spray, quantitative characteristic of fuel injection and the selection of the brake-up and evaporation model.

The angle of the fuel spray was specified experimentally, by measurement of the injection fuel in the atmospheric conditions $[15,27]$. Used in the research object the multihole fuel injector had marked the diameter of the holes and the angle of their location in relation to the axis of the injector. The aim of the measurements was to determine the spray cone angle of fuel injection and verification of the angle position of the holes in the injector. Measurements were made on a standard, manual stand for testing of fuel injectors, using photographic registration of $60 \mathrm{~Hz}$ frequency and 3.1 Mpix resolution. The angle of holes location equals $72^{\circ} \pm 1^{\circ}$, and the angle of the fuel spray cone equals $6^{\circ}$ $\pm 0.46^{\circ}$. The detailed description of mentioned measurements is presented in [15].

It should be noted, that value of the fuel spray angle, measured in the atmospheric conditions is specified low accuracy. The value of mentioned angle depends on density of fuel and mixture in the cylinder. The geometry of the fuel wania procesu spalania do przestrzeni samego cylindra. Podejście takie w znacznym stopniu zmniejsza czas obliczeń. Pełny opis budowy siatki zaprezentowano w pracy [16], a rzuty siatki w chwili przepłukania cylindra na rys. 1 .

Model dostarczania paliwa do cylindra wymaga określenia parametrów wtrysku paliwa, które w istotny sposób wpływają na proces spalania, a w konsekwencji na skład spalin. Parametrami tymi są: kąt rozwarcia strugi paliwa, charakterystyka ilościowa wtryskiwanego paliwa oraz wybór modelu rozpylania i parowania.

Kąt rozwarcia strugi wtryskiwanego paliwa określono eksperymentalnie, przez pomiary wtrysku paliwa w warunkach ciśnienia atmosferycznego [15]. Wykorzystywany w obiekcie badawczym wtryskiwacz paliwa $\mathrm{z}$ rozpylaczem wielootworkowym miał oznaczoną średnicę otworków oraz kąt ich rozmieszczenia względem osi wtryskiwacza. Celem pomiarów było określenie kąta stożka strugi paliwa oraz weryfikacja kąta położenia otworków we wtryskiwaczu. Pomiarów dokonano na standardowym, ręcznym stanowisku do testowania wtryskiwaczy paliwa za pomocą rejestracji fotograficznej z częstotliwością $60 \mathrm{~Hz}$ i rozdzielczością 3,1 Mpix. Kąt położenia otworków we wtryskiwaczu został ustalony na wartość $72^{\circ} \pm 1^{\circ}$, natomiast kąt stożka strugi paliwa był równy $6^{\circ} \pm 0,46^{\circ}$. Przebieg pomiarów bezpośrednich zaprezentowano w pracy [15] .

Należy zaznaczyć, że wartość kąta strugi paliwa, zmierzona $\mathrm{w}$ warunkach ciśnienia atmosferycznego, została określona jedynie orientacyjnie. Wartość tego kąta uwarunkowana jest stosunkiem gęstości paliwa do gęstości ośrodka, do którego paliwo jest wtryskiwane, a geometria 
spray depends on the shape [2] and position of the injector holes [20], the shape of holes edges and fuel properties [26], the movement of the mixture in the cylinder [19], and the process of fuel evaporation [21] also.

Quantitative characteristic of the fuel injection into the cylinders has a significant effect on the combustion process and the composition of the exhaust gas. Measuring the fuel injection pressure in the fuel line between, the fuel pump and the fuel injector allows to identify the characteristic of the fuel spray injected into the cylinder. For this reason, it is necessary to define and implement into the model the beginning of fuel injection, fuel injection time and the characteristic of the fuel injection.

In the classical construction of fuel equipment in the Diesel engine, the start of the fuel injection into the cylinders is set on the constant value of the angular position of the camshaft. The end of injection is determined by the position of the fuel rack, causing the rotation of the Bosch type fuel injection pump. In order to determine the angular position of the crankshaft during the beginning of fuel injection a vertical glass tube filled with fuel was installed at the fuel pump outlet. Angular position of the crankshaft for the start of the fuel injection was read for the moment, which fuel level in the glass tube began increasing. Observed angular position of the engine crankshaft for the beginning of fuel injection equals $18^{\circ} \pm 0.5^{\circ}$ before TDC.

Time and characteristics of fuel injection into the engine cylinders have been calculated on the basis of the analysis of the fuel pressure characteristic measured behind fuel injectors of the research object [12]. Fig. 2a presents the example of the fuel pressure characteristic measured during the engine operation at the $250 \mathrm{~kW}$ load. The horizontal line on the Fig. 2a presents the opening pressure of the fuel injector. It was assumed that the characteristic of the fuel pressure above the horizontal line is proportional to the

a)

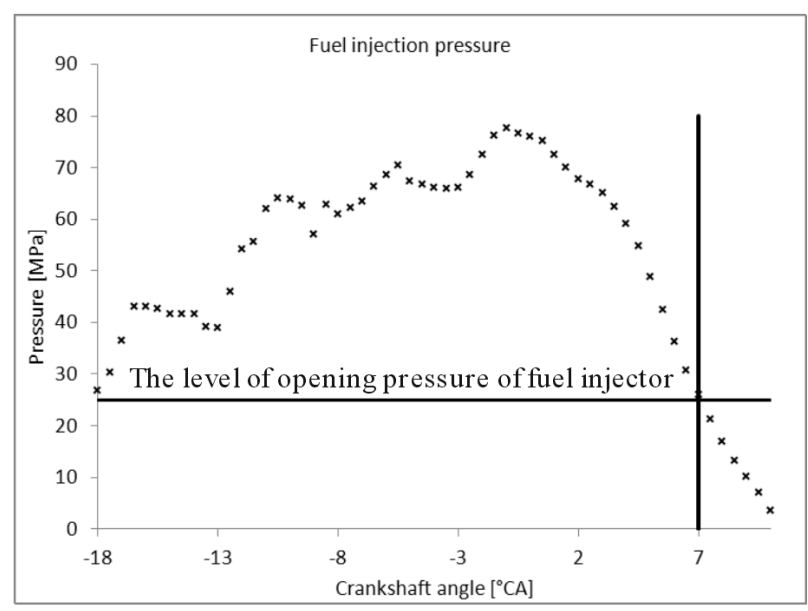

strugi paliwa zależy również od kształtu [2] i położenia otworków wtryskiwacza [20], kształtu krawędzi otworków oraz właściwości paliwa [26], ruchu mas w ośrodku [19] i przebiegu procesu parowania paliwa [21].

Charakterystyka ilościowa wtrysku paliwa do cylindrów ma istotny wpływ na przebieg procesu spalania i skład gazów wylotowych. Pomiar charakterystyki ciśnienia wtrysku paliwa w przewodzie paliwowym łączącym pompe wtryskową z wtryskiwaczem paliwa umożliwia określenie masowej charakterystyki strugi paliwa wtryskiwanego do cylindra. Z tego powodu konieczne jest określenie i zaimplementowanie do modelu początku wtrysku paliwa, czasu wtrysku paliwa oraz charakterystyki wtrysku paliwa.

W klasycznej konstrukcji aparatury paliwowej silnika o zapłonie samoczynnym początek wtrysku paliwa do cylindrów jest ustalony przez producenta na stałą wartość kątowego położenia wału rozrządu. Koniec wtrysku jest determinowany położeniem listwy paliwowej, powodującej obrót tłoczków pomp wtryskowych typu Boscha. Do określenia kątowego położenia wału korbowego obiektu badawczego dla początku wtrysku paliwa zainstalowano pionową rurkę szklaną, wypełnioną paliwem na króciec tłoczny pompy wtryskowej. Kątowe położenie wału korbowego dla początku wtrysku paliwa odczytano dla chwili, w której rozpoczął się wzrost poziomu paliwa w rurce szklanej. Odczytany kąt początku wtrysku paliwa do cylindrów obiektu badawczego wynosił $18^{\circ} \pm 0,5^{\circ}$ przed górnym martwym położeniem tłoka.

Czas oraz charakterystyka wtrysku paliwa do cylindrów obiektu badawczego zostały obliczone na podstawie analizy charakterystyki ciśnienia paliwa, zmierzonej na przewodach paliwowych przed wtryskiwaczami obiektu badawczego [12]. Na rysunku 2a zaprezentowano przykładową charakterystykę ciśnienia wtrysku paliwa, zarejestrowaną podczas pracy obiektu badawczego uznanego za sprawny, z obcią-

b)

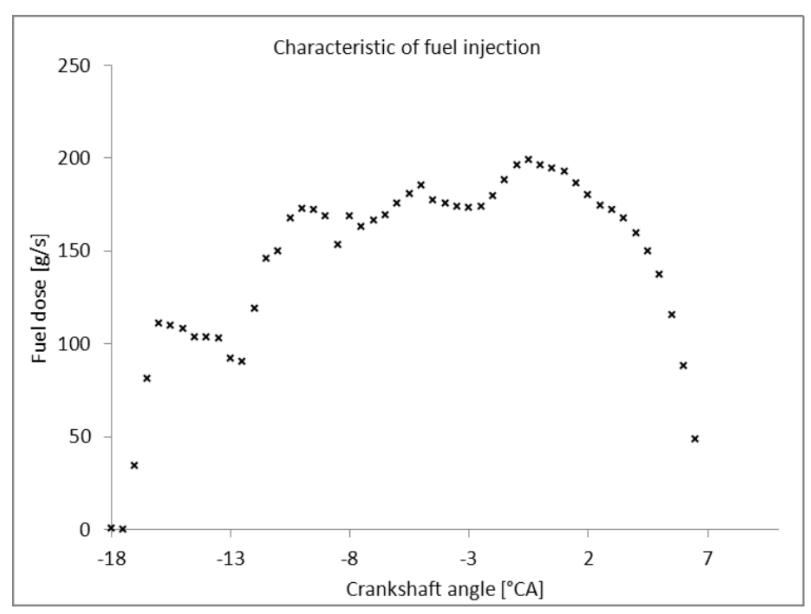

Fig. 2. The method of fuel injection characteristic determination: a) the example of the fuel injection pressure characteristic, b) obtained mass characteristic of the fuel injection

Rys. 2. Metoda wyznaczania masowej charakterystyki wtrysku paliwa: a) przyktadowa charakterystyka ciśnienia wtrysku paliwa, b) uzyskana masowa charakterystyka wtrysku paliwa 
mass characteristic of the fuel injection. This assumption is correct for neglecting of the inertia of moving parts of the fuel injector and the delay of the fuel injection, resulting from the length and shape of the hydraulic hose between the measuring sensor and the injector. The mass of injected fuel was calculated on the basis on the measurement of fuel consumption, and the characteristic of the fuel injection has been determined on the basis of characteristic of the injection pressure.

It was assumed that, according to Bernoulli equation, the mass flow of the injected fuel is proportional to the square root of the pressure difference between fuel and the combustion chamber. The example of the mass characteristic of the fuel injection is presented in Fig. $2 b$.

The WAVE fuel brake-up model [6] with the Wakisaka modification [29] and the Dukowicz evaporation model [4] were used in this work. The 3Z-ECFM [3] model of combustion process was chosen. This model allows to the auto-ignition point calculation also. Considered model is based on the Euler description [32]. The amount and the composition of the mixture in each finite volumes of the moving mesh are based on the average of Navier-Stokes equations and continuity equations. The turbulent flow in the finite volume model was calculated by the k-zeta-f model [8]. The SIMPLE model [11] was used to pressure correction in the finite volumes during the iterative calculations. Values of under relaxation factors were corrected for all balance equations and all considered angular positions of the crankshaft. The selection of mentioned factors allows to obtain correct results in no more than 100 iterations for each equation with assumed accuracy of the calculations at the level of $1 \%$. The "upwind" differential scheme was used to calculate energy balances and turbulent flows. The central scheme of differential equations was used to calculate the flow continuity equations. The variable step of calculations was defined also. During the compression stroke, the calculation step equals $1^{\circ}$ of the crankshaft angular position. This step was reduced to the value of $0.02^{\circ}$ of the angular crankshaft position at the time of the fuel brake-up, evaporation and ignition and during the early stage of exhaust valve opening. The average number of calculation steps equals 2830 for a full rotation of the crankshaft.

Chemical reactions of the combustion process in the 3Z-ECFM model taking place in a relatively small volume of the cylinder. It's assumed that in this area the homogeneous mixture of fuel and air is combusted. The alternate fuel composition in the form of a mixture of hydrocarbons with molar ratio of carbon to hydrogen equals $\mathrm{C}_{13} \mathrm{H}_{23}$ was adopted. The stoichiometric equations were used to determine the molar concentration of chemicals involved in the mechanisms of the $\mathrm{NO}_{\mathrm{x}}$ formation also. The Zeldowicz's and the Fenimore mechanisms are used simultaneously.

The heat transfer phenomena were implemented for each finite volumes, located on the exterior surfaces of the moving mesh. The third type of boundary conditions was żeniem równym $250 \mathrm{~kW}$. Na charakterystyce wyznaczono linię poziomą, określającą ciśnienie otwarcia wtryskiwacza. Przyjęto, że charakterystyka ciśnienia paliwa powyżej linii poziomej jest proporcjonalna do charakterystyki wtrysku paliwa. Założenie to jest słuszne w przypadku pominięcia bezwładności elementów ruchomych wtryskiwacza oraz opóźnienia wtrysku paliwa, wynikających z długości i kształtu przewodu hydraulicznego między czujnikiem pomiarowym a wtryskiwaczem. Masę wtryskiwanego paliwa przypadającą na jedną dawkę paliwa w cylindrze obliczono na podstawie pomiaru zużycia paliwa, natomiast charakterystykę wtrysku paliwa wyznaczono na podstawie charakterystyki ciśnienia wtrysku.

Przyjęto przy tym, że zgodnie z równaniem Bernoulliego, strumień masy wtryskiwanego do cylindra paliwa jest proporcjonalny do pierwiastka z różnicy ciśnień paliwa i ośrodka. Uzyskaną przykładową charakterystykę dawki paliwa przedstawiono na rys. $2 \mathrm{~b}$.

W niniejszej pracy zastosowano model rozpylania paliwa WAVE [6] z modyfikacją Wakisaka [29] oraz model parowania Dukowicza [4]. Modelowanie procesu spalania przeprowadzono z zastosowaniem modelu 3Z-ECFM [3], który określa również punkt samozapłonu paliwa. W rozważanym modelu zastosowano opis Eulera [32]. Ilość i skład mieszaniny w każdej objętości skończonej ruchomej siatki przestrzennej są obliczane na podstawie uśrednionych równań Naviera-Stokesa i ciągłości przepływu. Do uśrednienia przepływu turbulentnego w objętościach skończonych zastosowano model k-zeta-f [8]. Posłużono się przy tym iteracyjnym algorytmem obliczeniowym SIMPLE [11] do korekcji ciśnienia w objętościach skończonych. Dokonano przy tym doboru współczynników podrelaksacji (under relaxation factors) dla każdego z rozpatrywanych równań bilansowych i każdego położenia wału korbowego. Dobór wspomnianych współczynników umożliwił uzyskanie poprawnych wyników w nie więcej niż 100 iteracji dla każdego równania, przy założonej dokładności obliczeń na poziomie $1 \%$. Do obliczeń wartości parametrów z równań bilansowych zastosowano metody rozwiązywania równań hiperbolicznych pierwszego rzędu w postaci schematu różnicowego „upwind" do obliczania bilansów energii i przepływów turbulentnych oraz schematu różnicowego centralnego do obliczania równań ciągłości przepływu. Zdefiniowano również zmienny krok obliczeń. Podczas suwu sprężania krok obliczeń był równy $1^{\circ}$ kątowego położenia wału korbowego. Krok ten ulegał zmniejszeniu do wartości $0,02^{\circ}$ położenia wału korbowego w chwili rozpylania paliwa, zapłonu i początku otwarcia zaworu wylotowego. Średnia liczba kroków obliczeń wynosiła około 2830 dla pełnego obrotu wału korbowego.

$\mathrm{W}$ modelu 3Z-ECFM reakcje chemiczne procesu spalania zachodzą w stosunkowo niewielkiej objętości przestrzeni cylindrowej na mieszaninie homogenicznej paliwa i powietrza. Do modelowania przyjęto zastępczy skład paliwa w postaci mieszaniny węglowodorów o stosunku molowym węgla do wodoru $\mathrm{C} 13 \mathrm{H} 23$. Zastosowano również równania stechiometryczne do wyznaczenia stę- 
used, by describing the flow of heat through the engine cylinder components to the cooling system by the radiation and the conduction phenomena. The constant values of the heat transfer coefficient, the thermal resistance and the emissivity were adopted. Boundary and initial conditions were determined on the basis of laboratory tests, which are described in detail in [12-14].

\section{The model results and validation}

Presented model allows to calculation parameters of the combustion process in the cylinder of the marine, turbocharged, 4-stroke, Diesel engine type AL25/30. Such engines are commonly used on the ships as propulsion of power generators (i.e. „Dar Młodzieży”, „Stena Spirit”). The engine parameters are presented in the Tab. 1.

The analysis of the calculation results is possible only after positive validation with results obtained by laboratory measurements. For this reason, characteristics of the combustion pressure in the engine cylinder and exhaust gas composition were validated. The measurement data, used to validate the parameters and initial and boundary conditions, applied to modeling were collected during the measurements described in the aforementioned work [12]. The Fig. 3 presents comparison of measured and calculated parameters. According to presented results the mean error of calculation for the combustion pressure equals $1.13 \%$ for the mean indication pressure (MIP) and $1.42 \%$ for the maximum combustion pressure for all considered loads of the engine. It should be noted that MIP is understood to mean value of pressure for overall volume of the cylinder and the engine operation with closed cylinder valves. Maximum differences between calculated and measured values of the combustion pressure were obtained for 70 $\mathrm{kW}$ of the engine load in the case of the maximum combustion pressure and for $50 \mathrm{~kW}$ of load in the case of the MIP. Mentioned differences equals $6.8 \%$ and $4.3 \%$ respectively. The scientific target of the paper is the modeling of the combustion process for the exhaust gas composition. For this reason on the Fig. 3 results of mole fraction validation for oxygen $\left(\mathrm{O}_{2}\right)$, carbon oxide $(\mathrm{CO}), \mathrm{CO}_{2}$ and $\mathrm{NO}_{\mathrm{x}}$ for the engine operated at constant speed equals $750 \mathrm{rpm}$ are presented. The composition of the exhaust gas at the time żeń molowych związków chemicznych, biorących udział w mechanizmach powstawania $\mathrm{NO}_{\mathrm{x}}$. Zastosowano łącznie mechanizm Zeldowicza oraz Fenimore'a.

W prezentowanym modelu wymiana ciepła jest zaimplementowana do każdej objętości skończonej, usytuowanej na zewnętrznych powierzchniach ruchomej siatki przestrzennej. Zastosowano warunki brzegowe trzeciego rodzaju, w postaci określenia natężenia przepływu ciepła przez elementy konstrukcyjne cylindra silnika do układu chłodzenia dzięki promieniowaniu i przewodzeniu ciepła. Przyjęto przy tym stałe wartości współczynnika przejmowania ciepła, oporu termicznego i emisyjności.

Warunki brzegowe i początkowe wyznaczono na podstawie badań laboratoryjnych, których przebieg przedstawiono w pracach [12-14].

\section{Walidacja i wyniki modelowania}

Prezentowany model umożliwił obliczenie parametrów procesu spalania w 4-suwowym, turbodoładowanym silniku okrętowym o zapłonie samoczynnym typu AL25/30. Silniki tego typu są powszechnie stosowane na statkach jako jednostki napędowe generatorów prądotwórczych (min. „Dar Młodzieży”, „Stena Spirit”). Podstawowe parametry silnika podano $\mathrm{w}$ tabeli 1 .

Analiza uzyskanych wyników obliczeń jest możliwa tylko po pozytywnej walidacji z wynikami pomiarowymi. Z tego względu dokonano walidacji charakterystyki ciśnienia spalania w cylindrze silnika oraz składu spalin. Dane pomiarowe zastosowane do walidacji oraz parametry początkowe i brzegowe zastosowane do modelowania zostały zebrane podczas pomiarów, opisanych w pracy [12]. Na rysunku 3 zaprezentowano porównanie wspomnianych parametrów obliczonych z wartościami wyznaczonymi na drodze pomiarów bezpośrednich. Zgodnie z prezentowanymi wynikami średni błąd obliczeń dla ciśnienia spalania wynosił $1,13 \%$ dla średniego ciśnienia spalania i 1,42\% dla maksymalnego ciśnienia spalania dla całego rozpatrywanego zakresu obciążeń. Należy zaznaczyć, że średnie ciśnienie spalania rozumiane jest tu jako wartość średnia ciśnienia dla całej objętości cylindra i okresu pracy silnika z zamkniętymi zaworami cylindrowymi. Największe różnice obliczonych wartości ciśnienia spalania w stosunku

Table 1. The laboratory engine parameters [13]

Tabela 1. Podstawowe parametry silnika Al25/30 [13]

\begin{tabular}{|l|c|c|}
\hline \multicolumn{1}{|c|}{ Parameter/ parametr } & Value/wartość & Unit/jednostka \\
\hline Max. electric power/moc maksymalna & 250 & $\mathrm{~kW}$ \\
\hline Rotational speed/prędkość obrotowa & 750 & $\mathrm{rpm}$ \\
\hline Cylinder number/liczba cylindrów & 3 & - \\
\hline Cylinder bore/średnica cylindra & 250 & $\mathrm{~mm}$ \\
\hline Stroke/skok tłoka & 300 & $\mathrm{~mm}$ \\
\hline Compression ratio/stopień sprężania & 12.7 & - \\
\hline Injector nozzle/wtryskiwacz paliwa & & \\
\hline Holes number/liczba otworków & 9 & $\mathrm{~mm}$ \\
\hline Holes diameter/średnica paliwa & & $\mathrm{MPa}$ \\
\hline Opening pressure/ciśnienie otwarcia & 0.325 & \\
\hline
\end{tabular}




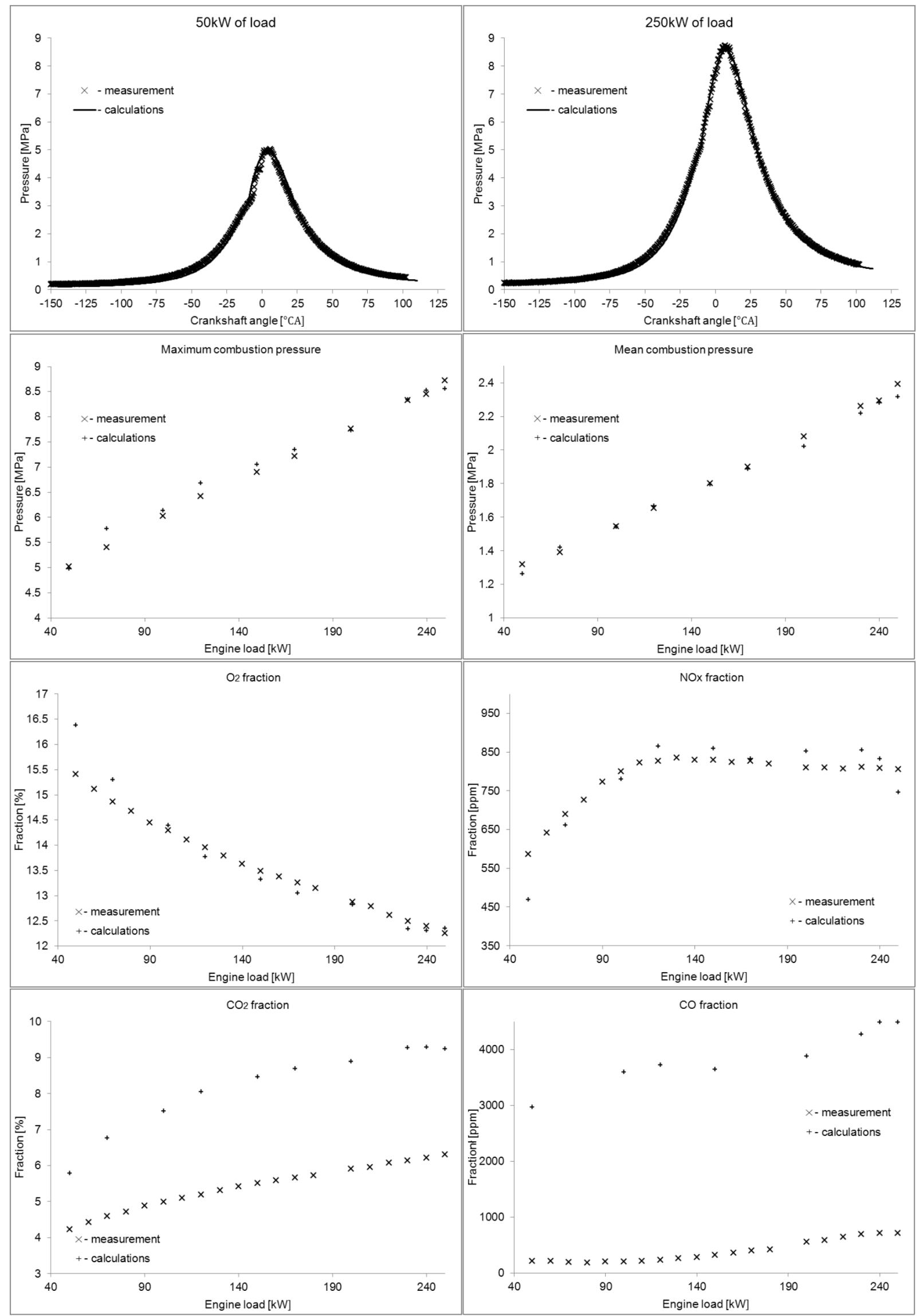

Fig. 3. Results of validation of calculated combustion pressure and the chosen chemical components of the exhaust gas Rys. 3. Wyniki walidacji obliczonych wartości ciśnienia spalania i wybranych składników spalin 


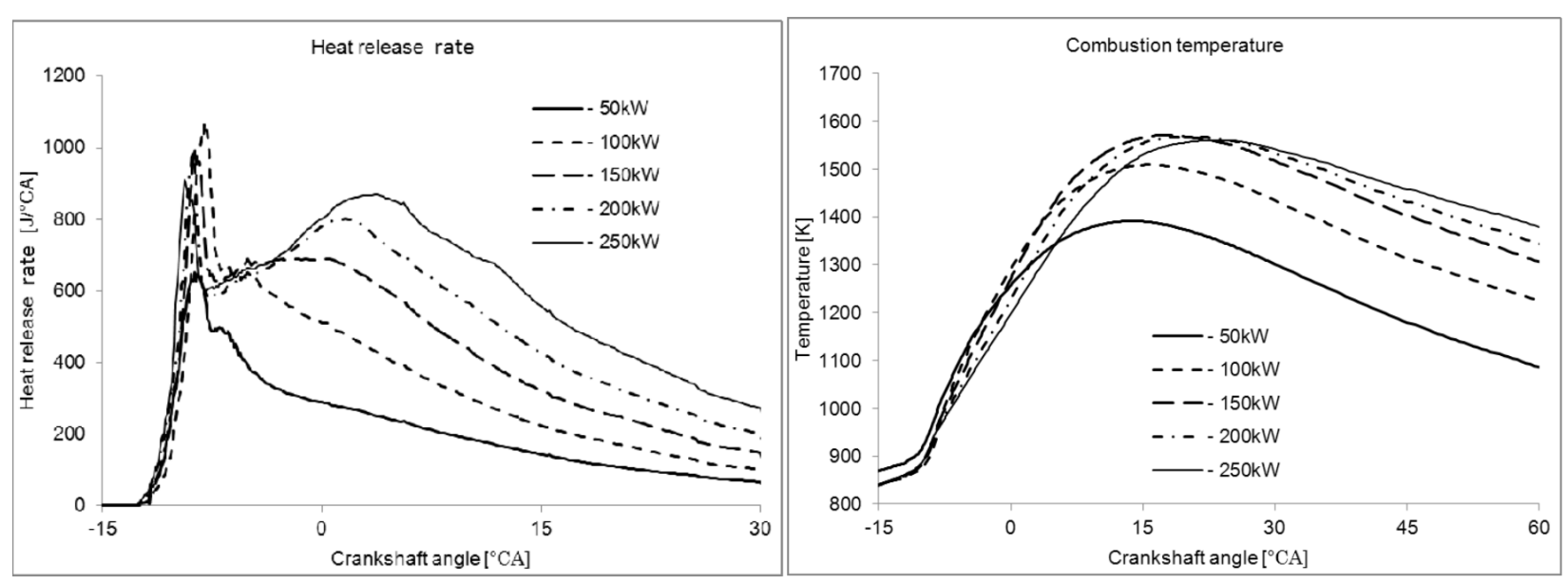

Fig. 4. Calculated the heat release rate and the mean combustion temperature for the overall volume of the cylinder Rys. 4. Obliczone szybkość wywiąywania się ciepła i średnia, dla całej objętości cylindra, temperatura spalania

of exhaust gas open was adopted. According to obtained results the mean error of calculation for $\mathrm{O}_{2}$ mole fraction equals $0.4 \%$ in relation to measured values and the maximum error equals $6.3 \%$ in the case of $50 \mathrm{~kW}$ of the engine load. The maximum error for the $\mathrm{NO}_{\mathrm{x}}$ mole fraction was observed in mentioned the engine load also. The maximum error equals $20 \%$ and the mean error for all considered loads of the engine equals $1.2 \%$.

The obtaining of valid results of fraction calculation of chemical compounds with carbon in the exhaust gas was failed. According to results presented in Fig. 3 the mean error of calculation in relation to measured values equals $49.4 \%$ for the $\mathrm{CO}_{2}$ fraction in the exhaust gas. Calculated values of $\mathrm{CO}$ fraction in the exhaust gas was average 5 times larger for $200-250 \mathrm{~kW}$ loads of the engine and it was increased with the engine load decreasing up to 16 times of the measured fraction. The possible reason of this fact is especially in poorly determining the shape of the fuel spray injected into the cylinder. As mentioned earlier, the shape of the injected fuel was measured in the atmospheric conditions. According to this, the next step of the research is the determination of mentioned parameter for the backpressure value closer to the values in the combustion chamber of the engine.

The Fig. 4 presents results of calculation of the heat release rate and the combustion temperature for considered loads of the engine.

Left side of the Fig. 4 presents the classic course of the heat release rate for Diesel engines. The heat release rate rapid increases after the fuel auto-ignition process. This is due to the combustion of the fuel dose, which evaporated until auto-ignition. This is named the kinetic stage of the fuel combustion. The following of the vapor fuel combustion, the heat release rate decreases. The fuel combustion from the larger droplets of fuel occurs. This stage of combustion is controlled by the diffusion phenomena, which course is slower than the kinetics stage of the combustion. According to presented results the increase of the engine load causes the increase of the combustion speed. It should do wartości zmierzonych uzyskano dla obciążenia silnika $70 \mathrm{~kW}$ przy maksymalnym ciśnieniu spalania i dla obciążenia $50 \mathrm{~kW}$ przy średnim ciśnieniu. Różnice te wynosiły odpowiednio $6,8 \%$ i $4,3 \%$.

Celem tej pracy było modelowanie procesu spalania w silniku do oceny składu emitowanych spalin, dlatego na rys. 3 zaprezentowano wyniki walidacji udziałów tlenu $\left(\mathrm{O}_{2}\right)$, tlenku węgla $(\mathrm{CO})$ oraz $\mathrm{CO}_{2}$ i $\mathrm{NO}_{\mathrm{x}}$ dla pracy silnika ze stałą prędkością obrotową równą $750 \mathrm{obr} / \mathrm{min}$. Przyjęto przy tym obliczony skład spalin w chwili otwarcia zaworu wylotowego. Zgodnie z uzyskanymi wynikami średni błąd udziałów tlenu w spalinach wynosi $0,4 \%$ w stosunku do wartości zmierzonych, przy błędzie maksymalnym wynoszącym $6,3 \%$ dla obciążenia silnika równego $50 \mathrm{~kW}$. Dla takiego obciążenia uzyskano również największy błąd dla udziałów $\mathrm{NO}_{\mathrm{x}}$ w spalinach. Wynosił on $20 \%$ przy średnim błędzie 1,2\% dla całego rozpatrywanego zakresu obciążeń. Nie uzyskano wiarygodnych wyników obliczeń dla udziałów związków węgla w spalinach. Zgodnie z wynikami zaprezentowanymi na rys. 3, średni błąd obliczeń w stosunku do wartości zmierzonych wynosił 49,4\% dla udziałów $\mathrm{CO}_{2}$. Obliczone wartości udziałów CO w spalinach były średnio 5-krotnie większe dla obciążenia silnika w przedziale $200-250 \mathrm{~kW}$ i zwiększyły się ze zmniejszeniem obciążenia silnika aż do 16-krotnej wartości udziałów zmierzonych. Przyczyn tego należy upatrywać przede wszystkim w niedostatecznie pewnym określeniu kształtu strugi paliwa wtryskiwanego do cylindra. Jak już wspomniano, kąt rozwarcia strugi paliwa został zmierzony w warunkach ciśnienia atmosferycznego. $Z$ tego powodu dalszym etapem badań jest określenie wspomnianych parametrów dla ciśnienia zbliżonego do wartości odpowiadających warunkom panującym w cylindrze silnika.

Na rysunku 4 podano wyniki obliczeń szybkości oraz średniej, dla całej objętości cylindra, temperatury spalania dla rozpatrywanych obciążeń silnika.

Z lewej strony rys. 4 można zaobserwować klasyczny przebieg szybkości spalania dla silników o zapłonie 
be noted, that for relatively low the engine loads the combustion process is determined by the kinetic combustion. It means that until the auto-ignition the most injected into the cylinder fuel dose is evaporated. The increase of the engine load causes the extension of the combustion process. The diffusive stage of the combustion begins to dominate in this case. The effect of this is the second increase of the combustion speed, observed in the Fig. 4. As the result of the extension of the diffusive phase of the combustion process the stabilization of maximum temperature of the combustion process with the increase of the engine load can be observed. Presented results are qualitatively similar to results presented by other authors [9].

\section{Conclusions}

The paper presents the combustion process model in the marine, turbocharged, 4-stroke, Diesel engine. The main scientific aim of the work is the assessment of the exhaust gas composition. The multi zone, 3-dimensional model of combustion process on the basis on the moving mesh was prepared. Obtained model allows to analysis the phenomena conducted in the engine cylinder. The validation of calculation results confirms the compliance of combustion pressure calculation results with measured values. Results of calculation of the $\mathrm{NO}_{x}$ and $\mathrm{O}_{2}$ fractions in the exhaust gas were validated also. According to obtained results, the mean value of the oxygen fraction in exhaust gas equals $0.4 \%$ in relation to measured values. The maximum error for the oxygen fraction equals $6.3 \%$. The mean error of calculation for $\mathrm{NO}_{\mathrm{x}}$ fraction equals $1.2 \%$ in relation to measured values. We do not get the correct results of calculations for the carbon chemical compounds fractions in exhaust gas. The reasons for this state of affairs the author sees in the wrong estimation of the angle of injected fuel. The increase of injection environment pressure causes the increase of the angle of the injected fuel spray. According to this statement, scientific researches on the fuel spray phenomena were continued.

The project was supported by the National Science Centre in Poland, granted on the basis of decision No. DEC-2011/01/D/ ST8/07142

The project was supported by AVL Company according to University Partnership Program and license of AVL Fire software

Praca została sfinansowana przez Narodowe Centrum Nauki na podstawie decyzji Nr DEC-2011/01/D/ST8/07142 oraz byta wspierana przez firme AVL, producenta oprogramowania Fire i Boost, zgodnie z programem partnerskim „University Partnership”. samoczynnym. Po samozapłonie paliwa przyrost energii jest gwałtowny, co jest spowodowane spalaniem tej części paliwa, która odparowała do chwili samozapłonu. Jest to tak zwany kinetyczny etap spalania paliwa. Po spaleniu par paliwa szybkość spalania maleje. Następuje spalanie paliwa z większych kropel w strudze. Ten etap spalania jest kontrolowany przez zjawiska dyfuzji, których przebieg jest wolniejszy od spalania kinetycznego. Zgodnie z prezentowanymi wynikami wzrost obciążenia silnika powoduje wzrost szybkości spalania. Należy zaznaczyć, że przy relatywnie małych obciążeniach silnika proces spalania jest zdominowany przez spalanie kinetyczne. Oznacza to, że do chwili samozapłonu większość wtryskiwanej do cylindra dawki paliwa jest już odparowana. Wzrost obciążenia sprzyja wydłużeniu procesu spalania - wtedy w procesie spalania zaczynają dominować zjawiska dyfuzji. Efektem tego jest ponowny wzrost szybkości spalania (obserwowany na rys. 4). W wyniku wydłużenia etapu dyfuzyjnego procesu spalania można zaobserwować pewną stabilizację maksymalnej temperatury procesu spalania wraz ze wzrostem obciążenia silnika. Prezentowane wyniki są jakościowo zbieżne z wynikami dostępnymi w literaturze przedmiotu [9].

\section{Wnioski}

W pracy zaprezentowano model procesu spalania w 4-suwowym, okrętowym, turbodoładowanym silniku o zapłonie samoczynnym. Celem modelowania było określenie składu spalin. Zastosowano wielostrefowy trójwymiarowy model procesu spalania, zbudowany na podstawie ruchomej siatki przestrzennej. W wyniku prezentowanych prac zbudowano model, który umożliwia analizę zjawisk zachodzących w cylindrze silnika podczas procesu spalania. Walidacja obliczeń potwierdziła zgodność uzyskanych wyników ciśnienia spalania z wartościami zmierzonymi. Pozytywnie zwalidowane zostały również wyniki udziałów $\mathrm{NO}_{\mathrm{x}} \mathrm{i}_{2}$ w spalinach silnika. Zgodnie $\mathrm{z}$ uzyskanymi wynikami średni błąd udziałów tlenu w spalinach wynosi 0,4\% w stosunku do wartości zmierzonych, przy błędzie maksymalnym wynoszącym 6,3\%. Średni błąd dla udziałów $\mathrm{NO}_{\mathrm{x}}$ wynosił 1,2\% w stosunku do wartości zmierzonych. Nie uzyskano poprawnych wyników dla udziałów związków węgla w spalinach. Przyczyn tego autor niniejszego artykułu upatruje w nieprawidłowym oszacowaniu kąta strugi wtryskiwanego paliwa. Zwiększenie ciśnienia ośrodka, do którego wtryskiwane jest paliwo powoduje wzrost kąta stożka strugi paliwa. Zastosowano bowiem kształt strugi paliwa zmierzony w warunkach ciśnienia atmosferycznego. 


\section{Bibliography/Literatura}

[1] Arrègle J., López J.J., García J.M., Fenollosa C. Development of a zero-dimensional Diesel combustion model, Appl Therm Eng. 2003;23(11):1319-1331. doi:10.1016/S13594311(03)00080-2.

[2] Brusiani F., Falfari S., Pelloni P. Influence of the Diesel Injector Hole Geometry on the Flow Conditions Emerging from the Nozzle, Energy Procedia (2014) 45, 749-758.

[3] Colin O., Benkeida A. The 3-Zones Extended Coherent Flame Model (ECFM3Z) for Computing Premixed/Diffusion Combustion, Oil \& Gas Science and Technology 59-6 (2004), 593-609.

[4] Dukowicz J.K. Quasi-steady droplet change in the presence of Convection, Informal Report Los Alamos Scientific Laboratory. LA7997-MS.

[5] Eaton A.M, Smoot L.D., Hill S.C., Eatough C.N. Components, formulations, solutions, evaluation, and application of comprehensive combustion models, Prog Energy Combust Sci. 1999;25(4):387-436. doi:10.1016/S03601285(99)00008-8.

[6] Fushui L., Lei Z., Baigang S., Zhijie L., Schock H.J. Validation and modification of WAVE spray model for diesel combustion simulation, Fuel 87 (2008) 15-16, 3420-3427.

[7] Ghojel J., Honnery D. Heat release model for the combustion of diesel oil emulsions in DI diesel engines, Appl Therm Eng. 2005;25(14-15):2072-2085. doi:10.1016/j.applthermaleng.2005.01.016.

[8] Hanjalić K., Popovac M., Hadžiabdić M. A robust near-wall elliptic relaxation eddy-viscosity turbulence model for CFD, International Journal of Heat and Fluid Flow 25-6 (2004) 1047-1051.

[9] Heywood J.B. Internal Combustion Engine Fundamentals, McGraw-Hill, 1988.

[10] Jurdziński M. Planowanie efektywności energetycznej statków morskich. Prace Wydziału Nawigacyjnego Akademii Morskiej w Gdyni, 2013; 28:5-10.

[11] Kaludercic B. Parallelisation of the Lagrangian model in a mixed Eulerian-Lagrangian CFD algorithm, J Parallel Distrib Comput. 64-2 (2004) 277-284.

[12] Kowalski J. An experimental study of emission and combustion characteristics of marine diesel engine with fuel Injector malfunctions, Polish Maritime Research, 23 (2016) 1, 77-84. doi.org/10.1515/pomr-2016-0011.

[13] Kowalski J. An experimental study of emission and combustion characteristics of marine diesel engine in case of cylinder val-ves leakage, Polish Maritime Research, 22 (2015) 3, 90-98. doi.org/10.1515/pomr-2015-0061.

[14] Kowalski J. An experimental study of emission and combustion characteristics of marine diesel engine with fuel pump malfunctions, Applied Thermal Engineering, 65 (2014) 469476. doi: 10.1016/j.applthermaleng.2014.01.028.

[15] Kowalski J. Analiza parametrów rozpylania i parowania paliwa z wtryskiwacza 4-suwowego silnika okrętowego, Zeszyty Naukowe AM. (2014) 83, 98-109.

[16] Kowalski J., Jaworski P. 3D mesh model for RANS numerical research on marine 4-stroke engine, Journal of Polish CIMAC. 9 (2014) 1, 87-94

[17] Kuo K.K. Principles of combustion, Wiley. New Jersey 2005.

[18] Mohamed Ismail H., Ng H.K., Gan S. Evaluation of nonpremixed combustion and fuel spray models for in-cylinder diesel engine simulation, Appl Energy. 2012;90(1):271-279. doi:10.1016/j.apenergy.2010.12.075.
[19] Moon S., Bae C., Choi J., Abo-Serie E. The influence of airflow on fuel spray characteristics from a slit injector, Fuel 86 (2007) 3, 400-409.

[20] Park S.W., Reitz R.D., A gas jet superposition model for CFD modeling of group-hole nozzle sprays, Int J Heat Fluid Flow 30 (2009) 6, 1193-1201.

[21] Pastor J., Javierlopez J., Garcia J. A 1D model for the description of mixing-controlled inert diesel sprays, Fuel 87 (2008) 13-14, 2871-2885.

[22] Poinsot T., Veynante D. Theoretical and numerical combustion, Edwards 2005.

[23] Rakopoulos C.D., Antonopoulos K., Rakopoulos D.C., Hountalas D.T. Multi-zone modeling of combustion and emissions formation in DI diesel engine operating on ethanol-diesel fuel blends. Energy Convers Manag. 2008;49(4):625-643. doi:10.1016/j.enconman.2007.07.035.

[24] Rakopoulos C.D., Antonopoulos K., Rakopoulos D.C. Development and application of multi-zone model for combustion and pollutants formation in direct injection diesel engine running with vegetable oil or its bio-diesel, Energy Convers Manag. 2007;48(7):1881-1901. doi:10.1016/j. enconman.2007.01.026.

[25] Şahin Z., Durgun O. Multi-zone combustion modeling for the prediction of diesel engine cycles and engine performance parameters, Appl Therm Eng. 2008;28(17-18):2245-2256. doi:10.1016/j.applthermaleng.2008.01.002.

[26] Samimi Abianeh O., Chen CP. A discrete multicomponent fuel evaporation model with liquid turbulence effects, Int J Heat Mass Transf. 55 (2012) 23-24, 6897-6907.

[27] Soid S.N., Zainal Z.A. Spray and combustion characterization for internal combustion engines using optical measuring techniques - A review, Energy 36 (2011) 2, 724-741.

[28] Varol Y., Oztop H.F., Firat M., Koca A. CFD modeling of heat transfer and fluid flow inside a pent-roof type combustion chamber using dynamic model, Int Commun Heat Mass Transf. 2010;37(9):1366-1375. doi:10.1016/j.icheatmasstransfer.2010.07.003.

[29] Wakisaka T. et al. Numerical Prediction of Mixture Formation and Combustion Processes in Premixed Compression Ignition Engines, COMODIA (2001) 426.

[30] Załącznik VI do konwencji MARPOL 73/78. Przepisy o zapobieganiu zanieczyszczeniu powietrza przez statki oraz kodeks techniczny $\mathrm{NO}_{\mathrm{x}}$, Wydawnictwa Polskiego Rejestru Statku. Gdańsk 2000

[31] Zhou P., Zhou S., Clelland D. A modified quasi-dimensional multi-zone combustion model for direct injection diesels, Int J Engine Res. 2006;7(4):335-345. doi: 10.1243/14680874JER02604.

[32] Zienkiewicz O.C., Taylor R.L. Finite Element Method, Vol. 3 - Fluid Dynamics. Fifth Edition, Butterworth-Heinemann. Oxford 2000.

Jerzy Kowalski, DSc. DEng. - doctor in the Faculty of Marine Engineering at Gdynia Maritime University.

Dr hab. inż. Jerzy Kowalski - adiunkt na Wydziale Mechanicznym Akademii Morskiej w Gdyni. e-mail: jerzy95@vega.am.gdynia.pl 